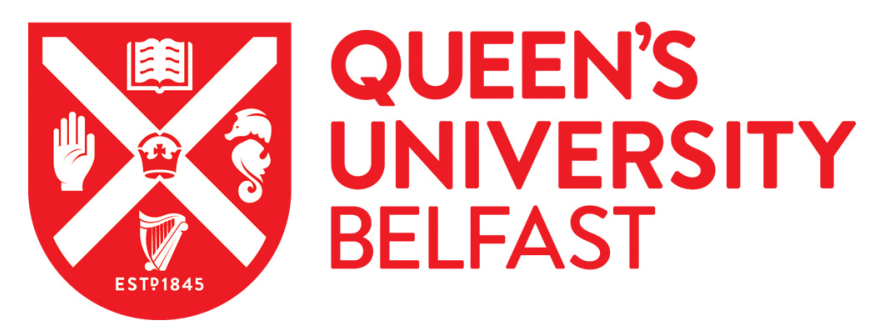

\title{
Fossil-fuelled development and the legacy of Post-Development theory in twenty-first century Africa
}

Andreasson, S. (2017). Fossil-fuelled development and the legacy of Post-Development theory in twenty-first century Africa. Third World Quarterly, 38(12), 2634-2649. https://doi.org/10.1080/01436597.2017.1334544

Published in:

Third World Quarterly

Document Version:

Peer reviewed version

Queen's University Belfast - Research Portal:

Link to publication record in Queen's University Belfast Research Portal

Publisher rights

(C) 2017 Southseries Inc.

This work is made available online in accordance with the publisher's policies. Please refer to any applicable terms of use of the publisher.

\section{General rights}

Copyright for the publications made accessible via the Queen's University Belfast Research Portal is retained by the author(s) and / or other copyright owners and it is a condition of accessing these publications that users recognise and abide by the legal requirements associated with these rights.

Take down policy

The Research Portal is Queen's institutional repository that provides access to Queen's research output. Every effort has been made to ensure that content in the Research Portal does not infringe any person's rights, or applicable UK laws. If you discover content in the Research Portal that you believe breaches copyright or violates any law, please contact openaccess@qub.ac.uk. 


\section{Fossil-fuelled development and the legacy of Post-Development theory in twenty-first century Africa*}

The last 40 years can be called the age of development. This epoch is coming to an end. The time is ripe to write its obituary.

We have got to be so impatient with moving Africa forward relentlessly - we have no choice. In 2025 there is absolutely no reason why Africa should not be totally lit up with the power it needs to industrialise...

-- Akinwumi Adesina, 2016

\section{Introduction}

This article examines the legacy of post-development theory, in particular its relevance and applicability to debates about Africa's future. Post-colonial Africa's marginal position in the global economy and international system of states ${ }^{1}$, combined with the propensity of orthodox development scholars to graft an essentially Western modernisation trajectory onto blueprints for socio-economic development in Africa $^{2}$, ought to have made the continent a fertile target for heterodox scholars considering alternatives forms of development and even alternatives to development. As pointed out by Matthews in one of the key contributions to post-development theory in Africa, 'many of the factors that led to the disillusionment of post-development theorists are prominent in Africa'. ${ }^{3}$ Nevertheless she also makes it clear that 'post-development

\footnotetext{
* Forthcoming in Third World Quarterly, special issue on '25 years after the Development Dictionary: Post-Development and its consequences'.
} 
has had little to say about Africa'. ${ }^{4}$ Indeed, it is not clear whether post-development theory and attendant societal critiques of development that proliferated in the last few decades of the twentieth century have had any lasting effect on how development is pursued in twenty-first century Africa.

To evaluate this question of post-development theory's legacy and its relevance to contemporary Africa, the article examines what lessons can be drawn by scrutinising post-development theory, and its claims about the end of development, through the prisms of Africa's pursuit of development and its political economy of energy. It considers the impact of these aspects of Africa's continued developmental efforts on the ability of post-development theory to provide insights into recent developments, such as the ideational and normative ramifications of pursuing socioeconomic development by means of an intensifying exploitation of Africa's fossil fuels in the current context of an increasing emphasis globally on renewable sources of energy and a transition to a low carbon economy. Revisiting basic claims of postdevelopment theory provides insights into the enduring disconnect and incommensurability between Africa's twenty-first century socio-economic trajectories and the core assumptions of post-development theory.

\section{Development, exhausted and rejuvenated}

The body of scholarship referred to as post-development theory constitutes the most fundamental critique and, for some of its adherents, total rejection of the modern notion of development as it emerged and became concretised in various policies and projects in the decades following World War II. ${ }^{5}$ Ziai identifies two main strands of post-development theory: a 'sceptical' one and a 'neo-populist' one. Neo-populism constitutes a more sweeping critique that is essentially 'anti-development' and prone 
to romanticise tradition and community. The 'sceptical' approach entails a more nuanced criticism commensurate with the emergence of a 'radical democratic' approach to development studies, wherein criticism of development recognises the political and economic power structures within which any fruitful debate on radical alternatives to the status quo must be located. ${ }^{6}$ The 'neo-populist' strand corresponds largely to what Simon describes as 'anti-development'. 'While the developments and trajectories identified in this article can more straightforwardly contribute to a refutation of the core claims of anti-development, they pose, as recently argued by Matthews ${ }^{8}$, serious questions for more nuanced versions of post-development theory too.

The opening declaration of Sachs's Development Dictionary in 1992 asserted that the era of development, predicated on modernisation by means of deepening the structures of capitalism including global economic integration, had proven itself unable to deliver the growing populations of the formerly colonised world from exploitation, poverty and related hardships. ${ }^{9}$ There had been, echoing Heilbroner's memorable phrase, no 'great ascent' of Empire's downtrodden ${ }^{10}$, but rather what Pritchett a few decades later described as 'divergence, big time' between Global North and South. ${ }^{11}$ Nowhere, it seemed, was that failure more pronounced than in Africa. The colonial history of Africa was one in which the continent's many misfortunes (oftentimes external in origin) have been combined and utilised by imperial rulers and scholars alike to produce a view of the continent as essentially inadequate, a place of systemic failure in terms of its ability to engage with and partake in the modern world. ${ }^{12}$

Despite rhetorical shifts in the post-colonial era, the core aspects of this Western view on Africa persisted and seemed also vindicated by empirical evidence. 
In sharp contrast to Africa's developmental potential as identified in the influential 1981 World Bank report, Accelerated Development in Sub-Saharan Africa, ${ }^{13}$ the 1980s saw the entrenchment and deepening of economic crises, violent conflicts and human suffering across the continent - indeed a 'Lost Decade'. ${ }^{14}$ Africa's developmental failures were documented in seminal works dissecting what Sandbrook described as the continent's 'economic stagnation', ${ }^{15}$ and van de Walle as its 'permanent crisis'. ${ }^{16}$ An even more damning verdict emerged from Easterly and Levine's influential study: 'Africa's economic history since 1960 fits the classical definition of tragedy: potential unfulfilled, with disastrous consequences'. ${ }^{17}$ Given the litany of failures, Africans were presumably yearning for alternatives to what was generally referred to by its critics as the modern development project, whether in its capitalist, socialist or Third Way guise.

Sachs and his colleagues identified the end of WWII and the emergence of the Cold War, and of the United States as the pre-eminent global power, as the beginning of the Era of Development, ${ }^{18}$ as would subsequently Rist in his History of Development. ${ }^{19}$ But while Sachs, and many post-development theorists with him, believed that, by the $1990 \mathrm{~s}$, this era has come to an end, we can still observe development's lodestar - the modern, industrialised and technologically advanced market state - shining bright across the firmament of the Southern skies. The primary difference today is that the notion of development is less Western-centric. ${ }^{20}$

A range of developmental models, all squarely embedded in the overarching context of modernisation are now on offer and thus competing with the Washington Consensus, ${ }^{21}$ a model that has also been reconsidered and revised. ${ }^{22}$ New offerings range from that of Chinese state capitalism, constituting the most significant competitor with the Western model, to various others as exemplified by the diverse 
examples of the BRICs (Brazil, Russia, India and China), ${ }^{23}$ and perhaps even in some extreme hybrid form the rapid and petroleum-fuelled modernisation of the Gulf states and their increasingly prominent role in global economic affairs. ${ }^{24}$ This diversity of approaches to development is a reminder of Simon's caution, that references in the anti- and post-development literature to a single or homogeneous 'development project ... is unhelpful, as there neither was nor is such a monolithic or singular construction, even during the heyday of modernization in the 1960 s and early 1970s. ${ }^{25}$

\section{Persistent pursuit of development}

If there is a waning of the West in terms of its influence globally, this does not mean the end of development. The strategic framework of the African Union's $2001 \mathrm{New}$ Partnership for Africa's Development (NEPAD), which constitutes the key panAfrican statement of the continent's ambitions for the twenty-first century, focuses squarely on the goal of sustained development by means of economic growth and poverty reduction. ${ }^{26}$ There is in NEPAD's declaration no substantial deviation from the key assumptions that have underpinned the Era of Development. It constitutes, according to Owusu's charting of Africa's developmental policy journey from the Dependency-inspired Lagos Plan to NEPAD, an 'endorsement of neoliberalism' ${ }^{27}$

What is needed is a commitment on the part of governments, the private sector and other institutions of civil society, to genuine integration of all nations into the global economy and body politic. This requires the recognition of global interdependence with regard to production and demand, the environmental base that sustains the planet, cross-border migration, a global financial 
architecture that rewards good socio-economic management, and global governance that recognises partnership among all peoples. We hold that it is within the capacity of the international community to create fair and just conditions in which Africa can participate effectively in the global economy and body politic. $^{28}$

While then South African president Thabo Mbeki enveloped these developmental and policy-specific aspirations in his broader vision for an 'African Renaissance', based on African values including the humanist notion of Ubuntu, one framework was not intended to replace the other. Rather, the values embodied in the African Renaissance, some of which align with post-development notions of valuing the local and respecting traditional systems of knowing and doing, would on this account facilitate the arrival of modernity albeit in African guise. ${ }^{29}$ What Africans want, according to this vision, is integration into the global economy on fair terms, not to reject mainstream development in order to seek radically different alternatives. It may be criticised as a very top-down and statesman-led approach to pursuing development, as opposed to one generated from the bottom up via civil society movements. But it is nevertheless the approach that has largely driven developmental policy across the continent, including in countries like South Africa where, according to Brooks, participatory democracy is 'largely considered to have failed' ${ }^{30}$ This even though the African Union's Common African Position (CAP) on the Post-2015 Development Agenda affords civil society a prominent place in the declaration of its 'participatory approach'. 31

In her recent re-examination of post-development theory in Africa, Matthews provides several illustration of a persistent 'desirability of development' across the 
continent. ${ }^{32}$ It is a continent exemplified by the aspirations of 'modern man', who embraces rather than rejects the basic components of development and which therefore casts doubt on the more strident of post-development theory's assumptions about 'what people want' in developing regions (i.e., the supposed rejection of pursuing greater economic growth and material affluence in favour of non-material and non-economic measures of well-being). Matthews identifies the high-profile case of 'service delivery protests' in South Africa as an example. These protests, very much driven by grassroots agency, are directed against the state's failure to deliver basic conditions associated with development - from access to flushing toilets to decent housing and jobs - and not against the notion of development itself. ${ }^{33}$ Critically, she argues that post-development theorists have failed to understand the degree to which conventional notions of development became vested with notions of justice and redress - i.e., the very desirability of development which is by some development critics all too easily dismissed simply a matter of African minds still being colonised. ${ }^{34}$ Having access to basic material necessities goes to the heart of human dignity, and the lack of such access remains a daily reminder of a previous colonial condition that gave rise to the current inequality in access in the first place.

That such commitments to development are evident across the Global South does not necessarily mean that post-development theory amounts to a failed intellectual project. But it does tell us something important about the resilience of development defined as modernisation, and about the challenges with which twentyfirst century post-development theorist must contend: emerging and complex forms of modernity that retain and reanimate tradition in ways not easily accommodated by post-development theory, ${ }^{35}$ as well as resilient popular support, including in 
traditional communities, for orthodox manifestations of development ${ }^{36}-$ truly an elusive yet formidable hydra to be confronted by the post-development sceptic.

Thus Sachs's assertion that '[t]he idea of development stands like a ruin in the intellectual landscape' is hardly the view of development suggested by Africa's twenty-first century trajectory. ${ }^{37}$ Nor does his claim, that the idea of development has become 'outdated' and that, 'above all, the hopes and desires which made the idea fly, are now exhausted', seem plausible today. ${ }^{38}$ This is perhaps the most exaggerated statement in Sachs's and his fellow theorists' obituary for the Era of Development when judging it from the perspective of social and political developments in Africa today. The track record of development actors, including governments, development agencies and the 'NGO industry', has certainly been criticised. ${ }^{39}$ But the notion of a project that is exhausted seems an assertion too far.

A rather troubling conceptualisation of development is inherent in this particular account. There seems to be something aloof, even dismissive, inherent in the idea that development has, in Sachs's words, merely 'eliminated innumerable varieties of being human and have turned the world into a place deprived of adventure and surprise'. ${ }^{40}$ There are presumably some forms of 'adventure and surprise' that those who are coping with dire poverty might conceivably want to trade for comfort and predictability. In this sense, post-development becomes susceptible to what Corbridge referred to as 'wobbly romanticism' - 'only the rich get lonely, only the poor live hospitably and harmoniously' - and 'implausible politics' - 'we can all live like the Mahatma, or would want to'. ${ }^{41}$ We may be concerned about some manifestations and consequences of modernity in materially wealthy societies, but it was not only life outside society that, in Hobbes' vivid characterisation, was 'nasty, 
brutish and short'. That remains for many an apt description of life below the poverty line today.

\section{Africa Rising, and falling}

In contrast to the expectations embodied in the Development Dictionary and corresponding critiques of development, the twenty-first century saw the emergence of a rather more promising socio-economic trajectory of sustained economic growth across most of Africa, even if the World Bank points out that Africa's economic diversification was rather modest and vulnerability to swings in commodity prices remained high. ${ }^{42}$ From this new trajectory emerged the widely heralded notion of Africa Rising - an idea and a bold representation of a vigorous Africa, not merely another policy or blueprint. It emphasised Africa's economic growth and increasing foreign direct investment, ${ }^{43}$ as well as the region's favourable demographics and increasing purchasing power of its emerging middle class. ${ }^{44} \mathrm{EY}$ 's report, Africa 2030 - Realizing the Possibilities, was representative of the new global consensus on Africa's current trajectory:

Despite any lingering scepticism, the evidence of the continent's clear progress over the past decade is irrefutable. The reality is that a diverse range of African countries have now experienced consistent and robust growth for over a decade - certainly the longest period of sustained growth since most countries attained independence in the early 1960s. ${ }^{45}$

Africa was no longer an outlier, a developmental failure. Instead the continent had begun to contribute to global economic growth and would become the locus of 
investment and opportunity as other, more saturated regions of the Global South offered less impressive returns on capital. Demographers and corporations alike described an African Century that would make the world take note. This more positive analysis of the continent's economic and developmental potential and, crucially, its need to industrialise is emphasised in a wide range of international and regional declarations and policy frameworks, such as the 2016 G20 summit in Hangzhou, the Sixth Tokyo International Conference on African Development held in Nairobi that same year, the African Union's Agenda 2063 and the United Nations General Assembly resolution proclaiming the period 2016-2025 as the 'Third Industrial Development Decade for Africa'. Summarising the relevance of these frameworks and the imperative of African industrialisation, Li Yong, Director General of the United Nations Industrial Development Organization (UNIDO) asserts that, '[m]y numerous meetings with African leaders and visits to dozens of countries ... have convinced me that Africa is committed to industrialization' ${ }^{46}$

Then again, seemingly all good things come to an end. The claim about an exhaustion of the development project could be considered vindicated following the abrupt decline of the trajectory underpinning the notion of Africa Rising, beginning with the oil price crash and the end of the commodities super-cycle from around 2014 onwards. Combined with a failure to turn sustained economic growth into significant diversification of national economies, the sharp loss of export earnings for Africa's many commodity-dependent economies, and in particular the oil-exporting ones, has become a serious threat to the continent's overall economic progress. ${ }^{47}$ Thus another false start, another vindication of 'Afro-pessimism' - the tortuous trajectory of postcolonial Africa's economic woes reasserting itself yet again. ${ }^{48}$ Dismissing the idea of Africa Rising as lacking in substance, Taylor argues that we are instead witnessing a 
case of 'dependency redux' as the economic foundations of this success story are in fact much weaker than assumed:

[T]he story of 'Africa Rising' is just that, a story, where growth-for-growth's sake replaces development and the agenda of industrialisation and moving Africa up the global production chain has been discarded. Instead, Africa's current 'comparative advantage' as a primary commodity exporter is reinforced, even whilst such dynamics reproduce underdevelopment. This is celebrated as 'progress'. 49

This, then, are two tales of Africa: rising and falling. The question is whether Africa's post-colonial crises can ever been transcended by means of orthodox development, or whether this promise is bound to remain what Rahnema insisted was merely a 'deceitful mirage'? ${ }^{50}$ Pursuing development seems, however, the course that most African countries will choose to stay. Young argues that Africa's post-colonial state has been consigned to history, as of the 1990s 'eviscerated' by the combined forces of economic decline and market reform. ${ }^{51}$ Africans have ever since been forging their own identities and shaping their own goals, the colonial shadow ever receding. Those goals, however, remain remarkably well aligned with exogenous models of development on offer from the West and the rising powers of the Global South. The global system is in transition, but in some ways it also remains more stable and resilient than anticipated in terms of asymmetrical relations between its more and less powerful actors. African states and related actors remain marginalised in the international system, but also determined to improve their situation within that system 
as currently constituted rather than seeking to radically depart from it. ${ }^{52}$ The political economy of energy is one area that can provide useful insights into this determination.

\section{Fossil-fuelled development}

The question of energy, how to obtain it and how to use it, is inextricably intertwined with the notion of modernisation and development. That is, to develop is to exploit, to produce and to consume. In order to do all of these things energy is (along with finance/credit) one of the indispensable ingredients of sustaining and reproducing the modern world - what Di Muzio aptly describes as our 'petro-market civilisation'. ${ }^{53}$ In their introduction to Energy, Capitalism and World Order, Di Muzio and Ovadia explain how the harnessing of fossil fuels make possible the emergence of modern, industrial civilisation. ${ }^{54}$ Previously, in the 'age of efflorescences', 55

civilizations were more immediately tied to the rhythms of plant photosynthesis and the power of wind, water, animals and unfree labour... what we would today call 'economic growth' could flourish from time to time but was never sustained. ${ }^{56}$

In Carbon Democracy, Mitchell takes this argument further to show that twentieth-century modern democracy, via the power of organised labour, grows out of the coal-based fossil fuel economy. ${ }^{57}$ Fossil fuel-based energy has been the ultimate enabler of modernity, and no other endeavour symbolises the desire for development more than does the craving for energy. There is furthermore a strong correlation between energy usage and mainstream indicators of improvements in living circumstances, such as the UN's Human Development Index (HDI). ${ }^{58}$ 
In this context, then, the fact that there has emerged a big and very costly gap between demand and supply of energy in Africa becomes particularly relevant. McDonald demonstrates that,

Africa is the most under-supplied region in the world when it comes to electricity, but its economies are utterly dependent on it. This contradiction is explained in part by the enormous inequalities in electricity access, with mining and industry receiving abundant supplies of cheap power whilst more than 80 percent of the continent's residents remain off the power grid. ${ }^{59}$

Kessides estimates that 25 of 48 countries in sub-Saharan Africa are experiencing 'crippling' shortages of electricity and regular blackouts, resulting in a loss of $2.1 \%$ of the region's GDP. ${ }^{60}$ Mohammed, Mustafa and Bashir argue that 'access to modern energy is considered one of the foremost factors contributing to the disparity between developed and developing nations' ${ }^{61}$ This, according to McDonald, is the inevitable outcome of what he terms 'electric capitalism'. ${ }^{62}$ Electricity is 'an integral part of all capitalist activity', and since (especially southern) African economies are very electricity-intensive, with ambitious plans to massively increase electricity-generation capacity, the development of electricity markets, and energy markets generally, becomes a particularly useful way to understand broader dynamics of 'capitalist accumulation and crisis' on the continent. ${ }^{63}$ As but one example, the path-dependent nature of South Africa's energy-intensive and dependent economy, and the difficulties in producing concrete alternatives to it given its strong anchoring in the power structures of the state, has been outlined by Fine and Rustomjee in their 
seminal contribution on South Africa's 'Minerals-Energy-Complex', and more recently in analyses by Baker and colleagues and Scholvin. ${ }^{64}$

Africa's energy gap is greater than in any other developing region, and closing it has now become one of the key goals for African governments and the organisations in Africa and abroad that co-operate with them to pursue economic development. As the President of the African Development Bank, Akinwumi Adesina, described the situation to delegates of the Bank's annual meeting in Lusaka in May 2016:

Children learn in the dark. Businesses operate in the dark. Surgeries are done in the dark. The greatest hindrance to Africa's growth and development is lack of electricity. It is unacceptable that 138 years after Thomas Edison developed the light bulb, hundreds of millions of people cannot have access to electricity to simply light up the bulb in Africa. ${ }^{65}$

In addition to the human and economic costs of inadequate access to safe and reliable sources of energy, the energy gap stands today as a modern day indicator that indicts Africa's failure to develop. Whether or not economists and development scholars labour under a 'tyranny of GDP' that restricts and limits the ways in which we are able to understand what it means to develop and how we choose to measure progress, ${ }^{66}$ few argue with the significance of not being able to switch on the lights and have them stay on. The quest for access to energy goes to the very heart of the desire to transcend a debilitating state of affairs in which people die from pulmonary disease when, in the absence of power plants delivering reliable supplies of energy, they have to burn wood, dung and coal; where children cannot study after dark as 
electrical lighting is not available; and where their parents cannot afford their children's education as the lack of energy stands as a key impediment to job-creating economic growth.

In this context, intensifying efforts by African governments and energy companies in collaboration with international energy companies to exploit the continent's energy resources, and in particular its oil and natural gas deposits, ${ }^{67}$ are a testament to the enduring determination by governments and businesses to achieve development by means of modernisation. The primary goal across Africa's energyrich states today is not how to phase out the reliance on fossil fuels but how to more effectively exploit them, even if in combination with developing renewable options. As noted by Collier, the era of resource exploitation is nowhere near its end across the, when it comes to natural resources including fossil fuels, relatively underexplored and underdeveloped countries of the Global South. ${ }^{68}$

Thus the political, economic and technocratic questions about bridging Africa's energy gap revolve primarily around how to fully embrace and constructively exploit Africa's resource wealth while at the same time avoiding the 'resource curse' that has afflicted Africa's oil producing countries in particular. ${ }^{69}$ This, combined with a trajectory of increasing resource exploitation in the pursuit of economic growth and development, is as good an indicator as any of the lasting triumph of the Era of Development and the drive for modernisation. On all of these accounts, the African trajectory runs counter to the expectations of an exhausted development project as outlined in the first edition of Sachs's Development Dictionary and by postdevelopment theory more generally.

\section{Turning development Green}


It is by now also recognised that African countries will be among the ones most severely affected by climate change, which of course their own drives to industrialise and develop on the back of fossil fuels are contributing to. Consequently there are movements afoot across Africa whereby environmental groups, sometimes in collaboration with governments, push for a 'greener' future and are contributing to a reconfiguring the African state in the process. ${ }^{70} \mathrm{~A}$ transition to renewable sources of energy is also modestly under way and might increase to contribute two-thirds of the growth in demand for power by $2020 .^{71}$ International agreements such as the one reached in Paris in 2015 will also have some impact in nudging African countries in the direction of low-carbon alternatives. Munang and Mgendi argue that the Paris Agreement on climate change presents 'a unique opportunity... to realize the dream of an environmentally sustainable and economically flourishing continent. ${ }^{, 72}$

Others are however decidedly less optimistic. With an insider's view of the negotiations that produced the Paris Agreement, Dimitrov argues that it:

favors developed countries of the North, who won most of the key battles... [whereas it] is least fair to the African Group and other Least Developed Countries. It does not include references to their special circumstances, is weak on international dimensions for adaptation policy, and precludes any future claims for liability and compensation. ${ }^{73}$

But even allowing for a move towards a 'greening' of African economies, the core aims of orthodox development - notably the pursuit of economic growth and increasing market shares - remain in place. Considering the development of an ostensibly 'green economy' in South Africa, the continent's leader in renewable 
energy investments, Death argues that it is the decidedly liberal and market-driven discourse of 'green growth' that is being prioritised by South Africa's government: 'rather than a focus on limits and scarcity ... the emphasis is on new markets, new services, and new forms of consumption'. ${ }^{74}$ This growth model stands in stark contrast to other 'discourses' including what he terms a 'Green revolution', which entails a radical reconfiguration of economic activity to align with postdevelopmental concepts such as 'ecological virtues' and 'limits to growth', and 'Green transformation', which entails an 'explicit focus on social justice, equity and redistribution' where growth is a means rather than and end. ${ }^{75}$

It is through focusing on South Africa's 'brand' as a rising power, with a youthful and energetic population and a rich natural environment, and the country as the economic and political 'gateway to Africa', rather than its environmental and social contradictions, that South African can be positioned as a global leader on the green economy. ${ }^{76}$

China has emerged as a key contributor to rapidly increasing investments in renewables across the African continent (albeit from a very low base), especially in solar power and in particular in South Africa. ${ }^{77}$ Shen and Power explain that Chinese energy companies have been 'pushed' into African markets 'by the need to deal with over-production, excess capacity and over-investment' at home. ${ }^{78}$ In this case too, the main aim is to capture new markets and, by extension, offering alternative paths to socio-economic development. The goal of increasing and sustaining economic growth, industrialisation and technological diversification - in a sense, to modernise remains the same, even if it should ideally be accomplished with lower-carbon or 
non-carbon sources of energy. Environmental sustainability is not the main goal. Illustrating this point, Schmitz argues that even where key actors among the rising powers of the Global South support policies relevant to climate change mitigation, such as China's extensive involvement in renewable energy investments in Africa,

[they] are not primarily concerned with environmental or climate issues. Their prime concerns are securing energy for the nation or particular regions, fostering new green industries and making them competitive, creating jobs and incomes in these industries or laying the foundation for increasing public revenue. Mitigating climate change is not irrelevant, but it tends to be a cobenefit rather than a driver. ${ }^{79}$

Thus the central role of the political economy of energy, including its new manifestations in renewable sources of energy and the 'green economy', in shaping twenty-first century Africa's developmental trajectories is a key manifestation of the enduring legacy of the Era of Development. The emerging drive for alternatives to fossil fuels and achieving a low-carbon transition - granting that they should be successful (which remains is highly uncertain) - is manifestly not an attempt to find and offer alternatives to development as has been a primary ambition of the scholarly community of post-development theorists. Rather it is a move towards entrenching modernity across African societies by alternative means.

\section{Conclusion: the legacy of post-development?}

In the end we are, not surprisingly, left with a plethora of questions. While there is no scope to answer them all here, they are nevertheless worth acknowledging when 
considering the continued relevance of post-development theory for Africa and the Global South more generally. Just as Marx was long on the failings of capitalism but short on the nature of socialism, post-development theory is good at generating questions about development, but less prolific when it comes to identifying alternatives thereto. This is not necessarily a problem in itself, but it does mean that concluding thoughts on the legacy of post-development theory are inevitably going to be characterised by a degree of tentativeness.

What is the legacy of post-development theory, in Africa and across the Global South? Do the critiques of development as initially put forth by Sachs and colleagues stand vindicated? Do they have a future as meaningful, and effective, scholarly critiques of orthodox development thinking and practice? Can it be argued that, irrespective of whether or not concrete alternatives to development have been produced, post-development has nevertheless achieved a crucial intervention in the debates about development, thus forcing a change in the dominant development discourse by making it less replete with simplistic and taken-for-granted assumptions? As noted by Escobar, one of the most prominent contributors to these debates, the discourses themselves really do matter. ${ }^{80}$

Or is it, alternatively, the case that post-development has had its moment in the sun (or at least the seminar room), only to be eclipsed by subsequent economic developments and by an irrepressible belief in, and attraction to, development-asmodernisation and its attendant promise of a better life across the Global South? Is, therefore, the best way to understand what drives popular politics and societal change across the Global South today merely a case of Rostow's fifth and final stage of development, the 'Age of high mass consumption', finally achieving the status of universal dogma? ${ }^{81}$ Does the post-development ambition to move beyond the 
modernist development discourse, by arguing for alternatives to development (but failing to identify them), constitute what Storey characterised as a Pontius Pilate politics, ${ }^{82}$ whereby intellectuals wash their hands of the seemingly intractable problems of exploitation, poverty and human suffering that still afflict far too many people across the world - what in Kiely's and Corbridge's vivid dismissals of postdevelopment amounts to a detached and even insidious form of Ivory Tower romanticising of the Noble Savage and of global poverty? ${ }^{83}$ It is not an entirely straightforward judgment to make.

What seems clear is that, for at least the middle classes and more secure working classes of the Global South that have escaped the historical misery of the lumpenproletariat and modern day 'precariat', decades of economic globalisation have coincided with significant improvements in living circumstances. The problem is that those benefits have not been distributed evenly. The so-called Elephant Curve illustrates clearly who are the winners (middle and working classes across the Global South, and the very wealthy in the Western world), and losers (the very poorest across the Global South and the working and middle classes of the West) in a world of increasing economic globalisation. ${ }^{84}$ It is therefore difficult to accept assertions such as those made by Andrews and Bawa, that globalisation is 'inherently bad for the poor'. ${ }^{85}$ The existence of substantial numbers of winners, even among many losers, is furthermore significant because it makes a comprehensive, coherent and sustained challenge to the status quo on development that post-development theory aspires to that much more difficult and therefore unlikely.

So what do these developments entail for the legacy and continued relevance of post-development theory? It is evident that orthodox development strategies have produced significant winners across the Global South, if less so in Africa. This is the 
case even if development as conventionally understood and pursued will never become a panacea for all of the world's poor - neither perfect positive-sum game, nor inevitably zero-sum. To the extent that these beneficiaries of development gain a more prominent voice in public discourses and national politics across the world, including in Africa (even though the continent remains home to so many of those who have not yet benefitted), we can expect that the ideational influence and normative power of development by means of economic growth and modernisation will remain an attractive proposal.

There are those who may find little hope in what is on offer and may therefore give up on development, considering it the ultimate pretence and diversion in an unsustainable world. But the idea and promise of development retains for a vast majority of the world's population the potency it has acquired since the Enlightenment and industrial revolution. Indeed, Matthews begins her recent analysis of the relevance of post-development theory to Africa by acknowledging that Sachs, in the preface to the new edition of his Development Dictionary, now recognises that the Global South has become 'the staunchest defender of development' ${ }^{86}$ Indeed, he has come to recognise the extent to which the idea of development has 'been charged with hopes for redress and self-affirmation'. ${ }^{87}$ This intertwining of the idea of development with desires for justice and improvement across the Global South is in line with the argument pursued throughout this article. Thus to offer something more appealing and attractive than what has manifestly become a primary pursuit of societies worldwide in the Era of Development remains the challenge for development's detractors. 


\section{Bibliography}

Adesina, Akinwumi. "Speech delivered by President Akinwumi Adesina at the opening session of the Annual Meetings of the African Development Bank Group.” Lusaka, Zambia, May 24, 2016. Accessed October 20, 2016. http://www.afdb.org/en/news-and-events/article/speech-delivered-bypresident-akinwumi-adesina-at-the-opening-session-of-the-annual-meetingsof-the-african-development-bank-group-lusaka-zambia-may-24-2016-15717/

African Union. The New Partnership for Africa's Development (NEPAD). Abuja: NEPAD, 2001. Accessed October 20, 2016. http://www.nepad.org/resource/new-partnership-africas-development African Union. Common African Position (CAP) on the Post-2015 Development Agenda. Addis Ababa: African Union. Accessed February 7, 2016. http://www.who.int/pmnch/development_agenda.pdf?ua=1

Andreasson, Stefan. "Orientalism and African development studies: the 'reductive repetition' motif in theories of African underdevelopment." Third World Quarterly 26, no. 6 (2005): 971-986.

Andreasson, Stefan. Africa's Development Impasse: Rethinking the Political Economy of Transformation. London: Zed Books, 2010.

Andreasson, Stefan. "Elusive Agency: Africa's Persistently Peripheral Role in International Relations." In African Agency in International Politics, edited by William Brown and Sophie Harman, 143-157. London: Routledge, 2013. Andreasson, Stefan. "American and British Strategies in the Competition for Energy Resources in Sub-Saharan Africa." In A New Scramble for Africa: The Rush for Energy Resources in Sub-Saharan Africa, edited by Sören Scholvin, 13-31. Farnham: Ashgate, 2015. 
Andrews, Nathan, and Sylvia Bawa. “A Post-development Hoax? (Re)-examining the Past, Present and Future of Development Studies." Third World Quarterly 35, no. 6 (2014): 922-938.

Baker, Lucy, Newell, Peter and Phillips, Jon. “The Political Economy of Energy Transitions: The Case of South Africa." New Political Economy 19, no. 6 (2014): 791-818.

Bush, Ray, and Graham Harrison. "New African development?” Review of African Political Economy 42, sup1 (2014): S1-S6.

Bremmer, Ian. "The end of the free market: who wins the war between states and corporations?" European View 9, no. 2 (2010): 249-252.

Brooks, Heidi. "The mass movement and public policy: discourses of participatory democracy in post-1994 South Africa.” Journal of Modern African Studies 55, no. 1 (2017): 105-127.

Coates Ulrichsen, Kristian. "The GCC States and the Shifting Balance of Global Power." CIRS Occasional Papers, Washington: Georgetown University. Accessed October 20, 2016. https://repository.library.georgetown.edu/bitstream/handle/10822/558292/CIR SOccasionalPaper6KristianCoatesUlrichsen2010.pdf

Collier, Paul. The Plundered Planet: Why We Must-and How We Can-Manage Nature for Global Prosperity. Oxford: Oxford University Press, 2010.

Corbridge, Stuart. "“Beneath the pavement, only soil': the poverty of postdevelopment.” Journal of Development Studies 34, no. 6 (1998): 138-148.

Death, Carl. The Green State in Africa. New Haven: Yale University Press, 2016. 
De Vries, Peter. “Don’t Compromise Your Desire for Development! A Lacanian/Deleuzian rethinking of the anti-politics machine." Third World Quarterly 28, no. 1 (2007): 25-43.

Dimitrov, Radoslav S. “The Paris Agreement on Climate Change: Behind Closed Doors." Global Environmental Politics 16, no. 3 (2016): 1-11.

Di Muzio, Tim. "Capitalizing a future unsustainable: Finance, energy and the fate of market civilization." Review of International Political Economy 19, no. 3 (2012): 363-388.

Di Muzio, Tim. Carbon Capitalism: Energy, Social Reproduction and World Order. London: Rowman and Littlefield International, 2015.

Di Muzio, Tim, and Jesse Salah Ovadia. Energy, Capitalism and World Order: Toward a New Agenda in International Political Economy. Basingstoke, Palgrave Macmillan, 2016.

Easterly, William. "The cartel of good intentions: The problem of bureaucracy in foreign aid." The Journal of Policy Reform 5, no. 4 (2002): 223-250.

Easterly, William, and Ross Levine. “Africa's Growth Tragedy: Policies and Ethnic Divisions." Quarterly Journal of Economics 112, no. 4. (1997): 1203-1250.

Escobar, Arturo. "The Making and Unmaking of the Third World through Development." In The Post-Development Reader, edited by Majid Rahnema (with Victoria Bawtree), 85-93. London: Zed Books, 1997.

EY Africa. Africa 2030 - Realizing the possibilities. EYAfrica, 2014. Accessed October 22, 2016. http://emergingmarkets.ey.com/wpcontent/uploads/downloads/2014/10/187.-EY-Africa-2030-realizing-thepossibilities.pdf 
Fine, Ben and Rustomjee, Zavareh. The Political Economy of South Africa: From Minerals-Energy Complex to Industrialization, London: Hurst, 1996.

Heilbroner, Robert L. The Great Ascent: The Struggle for Economic Development in Our Time. New York, Harper \& Row, 1963.

Gyekye, Kwame. Tradition and Modernity: Philosophical Reflections on the African Experience, Oxford: Oxford University Press, 1997.

Kanbur, Ravi. “The New Partnership for Africa's Development (NEPAD): An Initial Commentary.” Working Paper 2002-01. Ithaca: Department of Applied Economics and Management, Cornell University. Accessed October 21, 2016. http://ageconsearch.umn.edu/bitstream/127267/2/Cornell_Dyson_wp0201.pdf

Kessides, Ioannis N. 'Powering Africa's sustainable development: The potential role of nuclear energy." Energy Policy 74, sup. 1 (2014): S57-S70.

Kiely, Ray. "The Last Refuge of the Noble Savage? A Critical Assessment of PostDevelopment Theory." The European Journal of Development Research 11, no. 1 (1999): 30-55.

Leftwich, Adrian. "Bringing politics back in: Towards a model of the developmental state." The Journal of Development Studies 31, no. 3 (1995): 400-427.

Linklaters. Renewable Energy in Africa: Trending rapidly towards costcompetitiveness with fossil fuels. London: Linklaters, 2016. Accessed October 24, 2016. http://linklaters.com/Insights/Thought-Leadership/RenewablesAfrica/Pages/Index.aspx

Martínez, Daniel M., and Ben W. Ebenhack. "Understanding the role of energy consumption in human development through the use of saturation phenomena." Energy Policy 36, no. 4 (2008): 1430-1435. 
Matthews, Sally. "Post-development theory and the question of alternatives: a view from Africa." Third World Quarterly 25, no. 2 (2004): 373-384.

Matthews, Sally. "Colonised minds? Post-development theory and the desirability of development in Africa." Third World Quarterly forthcoming (2017): 1-14.

McDonald, David A., ed. Electric Capitalism: Recolonising Africa On the Power Grid. London, Earthscan, 2009.

Michaels, Marguerite. "Retreat from Africa.” Foreign Affairs 72, no. 1 (1992-93): 93108.

Milanovic, Branko. Global Inequality: A New Approach for the Age of Globalization. Cambridge, MA: Harvard University Press, 2016.

Mitchell, Timothy. Carbon Democracy: Political Power in the Age of Oil. New York: Verso, 2011.

Mohammed, Y. S., M. W. Mustafa, and N. Bashir. "Status of renewable energy consumption and developmental challenges in Sub-Sahara Africa." Renewable and Sustainable Energy Reviews 27 (2013): 453-463.

Morse, Stephen and Bell, Simon. "Sustainable development indicators: the tyranny of methodology revisited." Consilience: The Journal of Sustainable Development 6, no. 1 (2011): 222-239.

Munang, and Mgendi. "The Paris climate deal and Africa." UN Africa Renewal. April 2016. Accessed October 24, 2016.

http://www.un.org/africarenewal/magazine/april-2016/paris-climate-deal-andafrica

Nederveen Pieterse, Jan. “After Post-Development.” Third World Quarterly 21, no. 2 (2000): 175-191. 
Nederveen Pieterse, Jan. "Global Rebalancing: Crisis and the East-South Turn." Development and Change 42, no. 1 (2011): 22-48.

Owusu, Francis. "Pragmatism and the Gradual Shift from Dependency to Neoliberalism: The World Bank, African Leaders and Development Policy in Africa." World Development 31, no. 10 (2003): 1655-1672.

Pritchett, Lant. "Divergence, big time.” The Journal of Economic Perspectives 11, no. 3 (1997): 3-17.

Rahnema, Majid. "Introduction.” In The Post-Development Reader, edited by Majid Rahnema (with Victoria Bawtree). London: Zed Books, 1997.

Rieff, David. "In Defense of Afro-Pessimism.” World Policy Journal 15, no. 4 (1998/99): 10-22.

Rist, Gilbert. The History of Development: from Western Origins to Global Faith. London: Zed Books, 2002.

Rodrik, Dani. "Goodbye Washington Consensus, Hello Washington Confustion? A Review of the World Bank's Economic Reform in the 1990s: Learning from a Decade of Reform." Journal of Economic Literature 44, no. 4 (2006): 973987.

Ross, Michael L. "The Political Economy of the Resource Curse.” World Politics 51, no. 2 (1999): 297-322.

Ross, Michael L. The Oil Curse: How Petroleum Wealth Shapes the Development of Nations. Princeton: Princeton University Press, 2012.

Rostow, Walt W. The Stages of Economic Growth: A Non-Communist Manifesto. Cambridge: Cambridge University Press, 1971.

Sachs, Wolfgang, ed. The Development Dictionary: A Guide to Knowledge as Power. London: Zed Books, 1992. 
Samba Sylla, Ndongo. "From a marginalised to an emerging Africa? A critical analysis." Review of African Political Economy 41, sup1 (2014): S7-S25.

Sandbrook, Richard. The Politics of Africa's Economic Stagnation. Cambridge: Cambridge University Press, 1985.

Schmitz, Hubert. "Who drives climate-relevant policies in the rising powers?" Third World Quarterly forthcoming (2017): 1-20.

Scholvin, Sören. "South Africa's Energy Policy: Constrained by Nature and Path Dependency." Journal of Southern African Studies 40, no. 1 (2014): 185-202.

Shen, Wei, and Marcus Power. "Africa and the export of China's clean energy revolution." Third World Quarterly forthcoming (2017): 1-20.

Shepard, Eric, and Helga Leitner. "Quo vadis neoliberalism? The remaking of global capitalist governance after the Washington Consensus." Geoforum 41, no. 2 (2010): 185-194.

Simon, David. "Development Reconsidered: New Directions in Development Thinking." Geografiska Annaler: Series B, Human Geography 79, no. 4 (1997): 183-201.

Stephen, Matthew D. "Rising powers, global capitalism and liberal global governance: A historical materialist account of the BRICs challenge." European Journal of International Relations 20, no. 4 (2014): 912-938.

Storey, Andy. "Post-Development Theory: Romanticism and Pontius Pilate politics." Development 43, no. 4 (2000): 40-46.

Taylor, Ian. "Dependency redux: why Africa is not rising." Review of African Political Economy 43, no. 147 (2016): 8-25.

Therborn, Göran. “Entangled Modernities.” European Journal of Social Theory 6, no. 3 (2003): 293-305. 
Vale, Peter and Maseko, Sipho. "South Africa and the African Renaissance." International Affairs 74, no. 2 (1998): 271-287.

van de Walle, Nicholas. African economies and the politics of permanent crisis, 19791999. Cambridge: Cambridge University Press, 2001.

World Bank. Accelerated Development in Sub-Saharan Africa: An Agenda for Action. Washington, DC: World Bank, 1981.

World Bank. Africa's Pulse: An analysis of issues shaping Africa's economic future.

Vol. 8, October 2013. Accessed October 21, 2016.

http://www.worldbank.org/content/dam/Worldbank/document/Africa/Report/ Africas-Pulse-brochure_Vol8.pdf

Yong, Li. “Africa’s Decade of Industrialization.” Project Syndicate. Accessed February 6, 2017. https://www.project-syndicate.org/commentary/africaindustrialization-potential-by-li-yong-2017-02

Young, Crawford. "The end of the post-colonial state in Africa? Reflections on changing African Political dynamics.” African Affairs 103, no. 410 (2004): 2349.

Ziai, Aram. "The ambivalence of post-development: between reactionary populism and radical democracy." Third World Quarterly 25, no. 6 (2004): 1045-1060.

Ziai, Aram, ed. Exploring Post-development: Theory and practice: problems and perspectives. London: Routledge, 2007. 


\section{Notes}

${ }^{1}$ Andreasson, "Elusive Agency".

${ }^{2}$ Andreasson, "Orientalism and African development studies".

${ }^{3}$ Matthews, "Post-development theory", 377.

${ }^{4}$ Ibid., 374.

${ }^{5}$ Nederveen Pieterse, “After Post-Development”; Rist, History of Development;

Simon, "Development Reconsidered”; Ziai, Exploring Post-development.

${ }^{6}$ Ziai, “The ambivalence of post-development"; see also Andreasson, Africa's

Development Impasse, ch. 3 .

${ }^{7}$ Simon, "Development Reconsidered."

${ }^{8}$ Matthews, "Colonised minds?"

${ }^{9}$ Sachs, Development Dictionary.

${ }^{10}$ Heilbroner, The Great Ascent.

${ }^{11}$ Pritchett, "Divergence, big time".

${ }^{12}$ Andreasson, "Orientalism and African development studies".

${ }^{13}$ World Bank, Accelerated Development.

${ }^{14}$ Michaels, "Retreat from Africa."

${ }^{15}$ Sandbrook, Africa's Economic Stagnation.

${ }^{16}$ van de Walle, Politics of Permanent Crisis.

${ }^{17}$ Easterly and Levine, “Africa's Growth Tragedy”, 1203.

${ }^{18}$ Sachs, Development Dictionary, 1.

${ }^{19}$ Rist, History of Development.

${ }^{20}$ Bremmer, "The End of the Free Market."

${ }^{21}$ See Sheppard and Leitner, "Quo vadis neoliberalism?"

${ }^{22}$ Rodrik, "Goodbye Washington Consensus." 
${ }^{23}$ Leftwich, "Bringing politics back in"; Nederveen Pieterse, "Global Rebalancing”; Stephen, "Rising Powers".

${ }^{24}$ Coates Ulrichsen, “The GCC States".

${ }^{25}$ Simon, “Development Reconsidered”, 186.

${ }^{26}$ Kanbur, "The New Partnership for Africa’s Development”.

${ }^{27}$ Owusu, “The Gradual Shift from Dependency to Neoliberalism”, 1656.

${ }^{28}$ African Union, New Partnership for Africa's Development, 8.

${ }^{29}$ Andreasson, Africa's Development Impasse; Vale and Maseko, "South Africa and the African Renaissance."

${ }^{30}$ Brooks, "The mass movement and public policy", 106.

${ }^{31}$ African Union, Common African Position.

${ }^{32}$ Matthews, "Colonised minds?"

${ }^{33}$ Ibid., 3-4.

${ }^{34}$ Ibid.

${ }^{35}$ Gyekye, Tradition and Modernity; Therborn, "Entangled Modernities".

${ }^{36}$ De Vries, "Don’t Compromise Your Desire."

${ }^{37}$ Sachs, Development Dictionary, 1.

${ }^{38}$ Sachs, Development Dictionary, 1.

${ }^{39}$ Easterly, "The cartel of good intentions".

${ }^{40}$ Sachs, Development Dictionary, 4.

${ }^{41}$ Corbridge, "Beneath the pavement, only soil."

${ }^{42}$ World Bank, Africa's Pulse, 9.

${ }^{43}$ Bush and Harrison, "New African development?"

${ }^{44}$ Samba Sylla, "From a marginalised to an emerging Africa?"

${ }^{45}$ EY Africa, Africa 2030, 3. 
${ }^{46}$ Yong, "Africa's Decade of Industrialization."

${ }^{47}$ Taylor, "Dependency redux."

${ }^{48}$ Rieff, "In Defense of Afro-Pessimism."

49 Taylor, "Dependency redux", 22.

${ }^{50}$ Rahnema, "Introduction”, $\mathrm{x}$.

${ }^{51}$ Young, "End of the post-colonial state."

52 Andreasson, "Elusive Agency."

${ }^{53}$ Di Muzio, "Capitalizing a future unsustainable.”

${ }^{54}$ Di Muzio and Ovadia, Energy, Capitalism and World Order.

${ }^{55}$ Di Muzio, Carbon Capitalism.

${ }^{56}$ Di Muzio and Ovadia, Energy, Capitalism and World Order, 6.

${ }^{57}$ Mitchell, Carbon Democracy.

${ }^{58}$ Martínez and Ebenhack, "Understanding the role of energy consumption."

${ }^{59}$ McDonald, Electric Capitalism, xv.

${ }^{60}$ Kessides, "Powering Africa's sustainable development", S58.

${ }^{61}$ Mohammed, Mustafa and Bashir, "Status of renewable energy consumption", 453.

${ }^{62}$ McDonald, Electric Capitalism, xv.

${ }^{63}$ Ibid.

${ }^{64}$ Baker et al., "The Political Economy of Energy Transitions"; Fine and Rustomjee, The Political Economy of South Africa; Scholvin, "South Africa's Energy Policy".

${ }^{65}$ Adesina, "Speech".

${ }^{66}$ Morse and Bell, "Sustainable development indicators”, 225.

${ }^{67}$ Andreasson, "Competition for Energy Resources in Sub-Saharan Africa".

${ }^{68}$ Collier, The Plundered Planet.

${ }^{69}$ Ross, "Political Economy of the Resource Curse"; Ross, The Oil Curse. 
${ }^{70}$ Death, The Green State in Africa.

${ }^{71}$ Linklaters, Renewable Energy in Africa, 6.

${ }^{72}$ Munang and Mgendi, "The Paris climate deal and Africa”.

${ }^{73}$ Dimitrov, "The Paris Agreement on Climate Change", 8.

${ }^{74}$ Death, "The Green Economy in South Africa", 8.

${ }^{75}$ Ibid., 6-7.

${ }^{76}$ Ibid., 2.

${ }^{77}$ Shen and Power, "Africa and the export of China's clean energy revolution.”

${ }^{78}$ Ibid., 12.

${ }^{79}$ Schmitz, "Who drives climate-relevant policies?", 1-2.

${ }^{80}$ Escobar, "Making and Unmaking of the Third World."

${ }^{81}$ Rostow, Stages of Economic Growth.

${ }^{82}$ Storey, "Post-Development Theory".

${ }^{83}$ Kiely, "Last Refuge of the Noble Savage"; Corbridge, "“Beneath the pavement, only soil.",

${ }^{84}$ Milanovic, Global Inequality.

${ }^{85}$ Andrews and Bawa, "Post-development Hoax?”, 926.

${ }^{86}$ Sachs, quoted in Matthews, "Colonised minds?", 1.

${ }^{87}$ Ibid., 5. 